\title{
Effect of GnRH analogues and octreotide treatment on apoptosis and the cell proliferation of endometrium adenocarcinoma cell lines
}

\section{Endometriyal adenokanser hücre serilerinde GnRH analoglar ve oktreotidin apoptozis ve hücre proliferasyonu üzerindeki etkileri}

\author{
Harika Bodur Öztürk¹, Birol Vural ${ }^{2}$, Eray Çalışkan², Seyhun Solakoğlu ${ }^{3}$ \\ ${ }^{1}$ Department of Obstetric and Gynecology, Acibadem Hospital, Istanbul, Turkey \\ 2 Department of Obstetric and Gynecology, School of Medicine, Kocaeli University, Kocaeli, Turkey \\ ${ }^{3}$ Department of Histology and Embryology, School of Medicine, Istanbul University, Istanbul, Turkey
}

\section{Abstract}

0 bjective: The aim of this study was to compare apoptotic and antiproliferative effects of gonadotropin-releasing hormone analogues and their combination with octeotide on endometrioid endometrial cancer cell lines.

Material and M ethod: Women diagnosed with endometrioid adenocarcinoma at the department of Gynecology and Obstetric of Kocaeli University Medical School were included in this research. Endometrium cancer cell lines obtained from three patients were used for this study. After trypsinization in $0.5 \%$ in calcium magnesium, free phosphate buffer solution (CMFPBS) cells were seeded on glass slides in 24-well plates containing DMEM-F12 medium and 10\% fetal calf serum as culture medium. Cells were incubated for 24 hours at $37 \circ \mathrm{C}$ in $5 \% \mathrm{CO} 2$. GnRH agonist leuprolide (Lucrin $1 \mu \mathrm{mol} / \mathrm{L}$ ), GnRH antagonist ganirelix (Orgalutran $1 \mu \mathrm{mol} / \mathrm{L}$ ), leuprolide with octreotide (Sandostatin 10-6 mol/L), ganirelix with octreotide and no drug were added to the wells. Apoptosis and cells proliferations were evaluated after 12, 24, 48 and $72^{\text {th }}$ hours of incubation. The percentage of apoptotic cells was evaluated by TdT mediated biotin-dUTP nick-end labeling (TUNEL) method; cell proliferation was assessed by bromodeoxyuridine (BrdU) incorporation.

Results: Apoptotic index in grade I EEC cell line among ganirelixoctreotide treated cells and leuprolide-octreotide combination therapy were respectively higher than the untreated control $(p<0.001$, $\mathrm{p}=0.001$ ). The number of apoptotic cells in grade II EEC cell line among leuprolide-octreotide and leuprolide were significantly $(p<0.001$, $p<0.001)$ higher than in controls. In grade III EEC cell line, the number of TUNEL positive cells among leuprolide, ganirelix and ganirelixoctreotide therapiy groups were significantly higher than in untreated control. Time dependent antiproliferative effect was obtained with leuprolide and leuprolide-octreotide in grade I EEC $(p<0.001, p<0.001)$. Grade II EEC cell line is not influenced by hormonotherapies. However, the antiproliferative effect was obtained with ganirelix, leuprolide and leuprolide-octreotide in grade III cell line.

Conclusion: GnRH analogues appears to have a direct effect, enhancing the apoptotic index and decreasing the cell proliferation in endometrial adenocancer cell lines.

(J Turkish-German Gynecol Assoc 2010; 11: 131-6)

Key words: Endometrial cancer, gonadotropin-releasing hormone analogues, octreotide, apoptosis, cell proliferation

Received: 1July, $2010 \quad$ Accepted: 12 August, 2010

\section{Özet}

Amaç: Bu çalışmanın amacı endometriyal adenokanser hücre serilerinde $\mathrm{GnRH}$ analoglan ve oktreotidin apoptozis ve hücre proliferasyonu üzerindeki etkilerini karşılaştrmaktr.

Gereç ve Yöntemler: Kocaeli Üniversitesi Tıp Fakültesi Kadın hastalıklan ve Doğum bölümünde tanı alımış olan endometriyal adenokanser vakalan çalışmaya alındı. Üç hastadan alınmış olan endometriyla kanser hücre serileri bu çalışmada kullanıldı. Tripinizasyon için \%0.5 lik kalsiyum magnezyum, free phosphate buffer solusyonda (CMFPBS) bekletilen hücreler daha sonra DMEM-F12 mediyumu ve \%10 dana fetus serumu içiren dishlere ekildi. Hücreler $37{ }^{\circ} \mathrm{C}$ in $\% 5 \mathrm{CO} 2$ de 24 saat inkübe edildiler. GnRH agonist leuprolide (Lucrin $1 \mu \mathrm{mol} / \mathrm{L}$ ), GnRH antagonist ganirelix (Orgalutran $1 \mu \mathrm{mol} / \mathrm{L}$ ), leuprolide ve octreotide (Sandostatin $10-6 \mathrm{~mol} / \mathrm{L}$ ), ganirelix ve octreotide ve ilaçsız gruplar olusturuldu. Apoptozis ve hücre proliferasonu inkübasyondan sonraki 12,24 , 48 ve 72 . saatlerde değerlendirildi. Apoptotik hücre oranı TUNEL yöntemi ile, hücre proliferasyonu ise bromodeoxyuridine (BrdU) ilavesiyle değerlendirildi. Bulgular: Grade I endometriyal kanser hücre serisindeki apoptotik index ganirelixoctreotide ve leuprolide-octreotide combination tedavileri alan gruplarda tedavisiz gruba göre anlamlı olarak daha yüksek olarak saptandi $(p<0.001, p=0.001)$. Grade II endometriyal kanser hücre serisindeki apoptotik index sayss leuprolide-octreotide ve leuprolide gruplannda kontrol gruba göre anlamlı olarak daha yüksek olarak saptandı $(p<0.001, p<0.001)$. Grade III endometriyal kanser hücre serisindeki TUNEL pozitif hücre oranı leuprolide, ganirelix and ganirelixoctreotide tedavisi alan gruplarda kontrol grubuna göre anlamlı olarak daha yüksek idi. Zamandan bağımsız antiproliferatif etkinlik leuprolide ve leuprolideoctreotide gruplannda grade 1 hücre serilerinde gözlendi $(p<0.001$, $p<0.001$ ). Grade 2 Grade I endometriyal kanser hücre serisinin hormon tedavisinden etkilenmediği görüldü. Buna karşın ganirelix, leuprolide ve leuprolide-octreotide gruplannda Grade III endometriyal kanser hücre serisinde antiproliferatif etkinlik saptand.

Sonuç: Öyle görülmektedir ki, endometriyal adenokanser hücre serilerinde $\mathrm{GnRH}$ analoglannın apoptotik indeksi yükseltme ve hücre proliferasyonu azaltma mekanizmalan ile direkt etkisi vardır.

(J Turkish-German Gynecol Assoc 2010; 11: 131-6)

Anahtar kelimeler: Endometriyal kanser, gonadotropin-releasing hormone analoglan, octreotide, apoptozis, hücre proliferasyonu

Geliş Tarihi: 01 Temmuz 2010 Kabul Tarihi: 12 Ağustos 2010 


\section{Introduction}

Endometrial carcinoma is the most common malignancy of the female genital tract (1). Despite the dominance of early stage disease, surgical treatment and/or irradiation are not curative for advanced endometrial cancer and the number of reported cancer deaths is increasing. Chronic elevated level of estrogen without the inhibitory effects of progesterone are considered stimuli for abnormal endometrial cell proliferation. Also, mutations in the tumour suppressor genes and microsatellite instability (MI) are common genetic abnormalities in endometrioid endometrial cancers (EEC), and distinguish these lesions from other histological subtypes of endometrial carcinomas (2).

Apoptosis and proliferation are the main factors in controlling both benign and malignant cell populations. Apoptosis is a physiological process leading to cell death characterized by cell shrinkage, membrane blebbing and DNA fragmentation and it is an important phenomenon existing in normal endometrium, regulated by sex steroids during the menstrual cycle $(3,4)$. In conditions where the concentrations of sex steroids are altered, the expression of apoptosis related proteins is susceptible to change. If the balance of the regulation of cell cycle is affected it thus induces a potential loss in the control of cell survival and may progress to cancer progression.

As endometrial cancer develops from generally hormone dependent cells, endocrine treatment has been the traditional palliative therapy of advanced or recurrent disease. Progestins have been used and currently $\mathrm{GnRH}$ analogues and their mechanism of effect have been investigated by many researchers. It has been demonstrated that about $50 \%$ to $80 \%$ of endometrial cancer express $\mathrm{GnRH}$ receptors, and recent researches have been focused on the possible use of GnRH agonists and antagonists as a potential target for the treatment of endometrial cancer (5-7).

Octreotide acetate is a synthetic octapeptide analogue of naturally occurring somatostatin with similar pharmalogical effects, but with a prolonged duration of action. It may act directly and specifically on neoplastic cells or indirectly via peptides and/or other substances that are crucial for neoplastic growth.

The aim of the study is to compare the apoptotic and proliferative effect of leuprolide, ganirelix, leuprolide combined with octreotide, ganirelix combined with octreotide and untreated control in human endometrioid adenocarcinoma cell culture to evaluate possible clinical use of these hormones for future treatment of advanced/ recurrent endometrial carsinoma.

\section{M aterial and Methods}

\section{Tissue samples}

Surgical specimens were obtained from three patients undergoing hysterectomy for endometrial cancer at the Department of Gynecology and Obstetrics of the Kocaeli University Medical School. All patients were post-menopausal, aged 56, 65 and 71 years. Tumor specimens were placed in ice cold phosphate buffer solution (PBS) immediately after surgical removal and representative portions were excised to prepare the materials for histological frozen section. Approximately $1 \mathrm{~mm}^{3}$ tumor tissue were utilised for the cell culture and the residue was sent for histological examination. Tumor grading of the paraffin- embedded tissue blocks were compatible with the preoperative diagnosis. This investigation was approved by the Institutional Ethics Committee of the Kocaeli University, School of Medicine. Informed written consent was obtained from all subjects.

\section{Cell culture}

Samples of human endometrioid type adenocarcinoma were obtained under sterile conditions in the surgical pathology unit. The tissue was immediately placed into the culture medium and processed within 60 minutes of collection. Single cells obtained by mechanical disruption were separated from the clumps by sedimentation and then removed. The bigger clumps that sedimented were digested in a 37으 shaking waterball for 1 hour with $1 \mathrm{mg} / \mathrm{ml}$ collagenase $B$ ve $0.1 \mathrm{mg} / \mathrm{ml}$ DNAase. The tissue was then washed in PBS.

After removal of the supernatant, pellets which had been diluted with one $\mathrm{ml}$ of the washing medium were filtrated through sieve number 46 (cell-dissociation sieve, Sigma-Aldrich) and the ultrafitrate was seeded on $25 \mathrm{~cm}^{2}$ tissue culture flasks and embedded $10 \mathrm{ml}$ DMEM-F12 medium with $10 \%$ fetal calf serum. The cells were cultured in a humidified atmosphere of $5 \%$ $\mathrm{CO}_{2}$ and $95 \%$ air at 370 $\mathrm{C}$ and passaged every 3 days after the 5 th day of incubation. After trypsinization in $0.5 \%$ in calcium magnesium free phosphate buffer solution (CMF-PBS), the cells were seeded on glass slides in 24-well plates containing DMEM-F12 (Dulbecco's modified Eagle's minimal essential medium) medium and $10 \%$ fetal calf serum as culture medium.

\section{Incubation}

Cells were incubated for 24 hours at $370 \mathrm{C}$ in $5 \% \mathrm{CO}_{2}$. Leuprolide acetate (Lucrin ${ }^{\circledR}$, Abbott, Chicago MI, USA) as GnRH agonist and ganirelix (Orgalutran ${ }^{\circledR}$, Organon) as $\mathrm{GnRH}$ antagonist in concentrations of $1 \mu \mathrm{mol} / \mathrm{L}$; and a combination of leuprolide with octreotide $10^{-6} \mathrm{~mol} / \mathrm{L}$ (Sandostatin $\AA$, Novartis, Quebec, Canada) and ganirelix with octeotide as somatostatin analogue were added to the wells. After 12 hours cells were removed for analysis of apoptosis and after 24,48 , and 72 hours groups, media were removed $1 \mathrm{hr}$ before the end points of each interval and the cells were incubated in $1 \mathrm{ml}$ of medium containing $20 \mu \mathrm{M}$ BrdU for the last hour.

\section{M easurement of apoptosis}

The percentage of apoptotic cells was assessed by the TUNEL technique following the manufacturer's instructions (In situ cell death detection kit, POD, Cat No.1 684 817, Roche Diagnostic) in the endometrial cancer cells cultures 12 hours after the addition of $\mathrm{GnRH}$ agonist Lucrin $1 \mu \mathrm{mol} / \mathrm{L}$ (Leuprolide ${ }^{\circledR}$, Abbott, Chicago MI, USA), GnRH antagonist Orgalutran $1 \mu \mathrm{mol} / \mathrm{L}$ (Ganireliks ${ }^{\circledR}$, Organon) and their combination with somatostatin analogue octreotide $10^{-6} \mathrm{~mol} / \mathrm{L}$ (Sandostatin ${ }^{\circledR}$, Novartis).

The cells were fixed for $30 \mathrm{~min}$ in $4 \%$ paraformaldehyde at room temperature. The cells were permeabilized with $0.1 \%$ TritonX-100 and $0.1 \%$ sodium citrate for 2 min at $4{ }^{\circ} \mathrm{C}$ and were then incubated at $37{ }^{\circ} \mathrm{C}$ for $60 \mathrm{~min}$ in the dark in $50 \mu \mathrm{L}$ TUNEL reaction mixture. Thereafter they were incubated with $50 \mu \mathrm{L}$ converter at room temperature for $20 \mathrm{~min}$.

\section{BrdU incorporation in vitro}

Detections of BrdU-labeled cells was performed using standard avidin-biotin complex methods immunoperoxidase kits 
(LabVision) with primary BrdU antibody (NeoMarkers). The cells were fixed in methanol at $-10^{\circ} \mathrm{C}$ for $1-2 \mathrm{~min}$, allowed to air dry, then stored at $-20^{\circ} \mathrm{C}$ until all coverslips were ready for processing. Cells were rehydrated in the PBS for $5 \mathrm{~min}$, followed by immersion in $2 \mathrm{~N} \mathrm{HCl}$ for $1 \mathrm{hr}$ at room temperature. The cells were incubated in $0.1 \mathrm{M}$ borate buffer ( $\mathrm{pH} 8.5,0.1 \mathrm{M}$ boric acid, $25 \mathrm{mM} \mathrm{Na}_{2} \mathrm{~B}_{4} \mathrm{O}_{7}$ and $75 \mathrm{mM} \mathrm{Na} \mathrm{Cl}$ ) twice for 5 min each, followed by 3 washes in PBS.The cells were then incubated with BrdU Mouse Mab (Bu2a) at a dilution of 1:100 for $1 \mathrm{hr}$ at 37으 with biotinylated secondary antibody (LabVision Cat. TM-060$\mathrm{HL}$ ) for $20 \mathrm{~min}$ and with streptavidin/peroxidase (LabVision Cat. TA-060-HA) for $30 \mathrm{~min}$ at room temperature. Subsequenty, sections were subjected to color reaction with $0.002 \%$ 3.3- diaminobenzidine tetrahydrochloride containing $0.005 \% \mathrm{H}_{2} \mathrm{O}_{2}$ in PBS ( $\mathrm{pH}$ 7.4) and lightly counterstained with hematoxylin.

\section{Cell counting}

The number of TUNEL positive stained cells and BrdU labeled cells were quantified by two independent observers in a blind manner. Apoptotic cells were detected by their red colour (Figure 1). Each observer viewed randomly selected 1000 cells in a light microscope at a magnification of 40X. The number of apoptotic cells was determined by apoptotic index (i.e., number of apoptotic cells per 100 cells) and BrdU labeled cells were expressed as the percentage of positive cells (Figure 2). There was no significant difference between the results of two observers $(p=0.23)$.

\section{Statistical analysis}

Statistical analysis were performed by Kruskal- Wallis nonparametric analysis using SPSS 11.5 (Statistical Programme For Social Sciences, IL, USA). The statistical significance of the difference between the control and hormonotherapy groups was determined by one-way Anova followed by Dunnett T3 test for multiple comparisons. A P value of less than 0.05 was considered significant.

\section{Results}

\section{A poptosis}

Figure 3 demonstrates that the TUNEL positive cells count after the $12^{\text {th }}$ hour of the treatment with leuprolide, ganirelix and their combination with octreotide was higher than the control group. In the grade I EEC cell line the number of apoptotic cell was higher $(2.5 \pm 0.52)$ than in the grade II $(0.7 \pm 0.48)$ and grade III $(0.3 \pm 0.48)$ adenocarcinoma cell line in the drug free group. Apoptotic index in the grade I EEC cell line among ganirelixoctreotide treated cells $(8.5 \pm 0.671)$ and leuprolide-octreotide combination therapy $(4.7 \pm 0.3)$ were respectively higher than in the untreated control $(2.5 \pm 0.167)$, which was statiscally significant $(p<0.001, p=0.001)$. The number of apoptotic cells in the grade II EEC cell line among leuprolide-octreotide (5.5 \pm 0.167$)$ and leuprolide (3.1 \pm 0.18$)$ were significantly $(p<0.001, p<0.001)$ higher than in the untreated control $(0.7 \pm 0.153)$. In the grade III EEC cell line, the number of TUNEL positive cells among leuprolide (4.4 \pm 0.819$)$, ganirelix (4.2 \pm 0.389$)$ and ganirelix-octreotide $(3.1 \pm 0.277)$ therapies groups were significantly $(p<0.001$, $p<0.001, p=0.002$ respectively) higher than the untreated control $(0.3 \pm 0.153)$ (Table 1$)$.

In the presence of $10^{-6} \mathrm{~mol} / \mathrm{L}$ octreotide, the apoptotic index of the grade I ECC cell line was significantly increased when

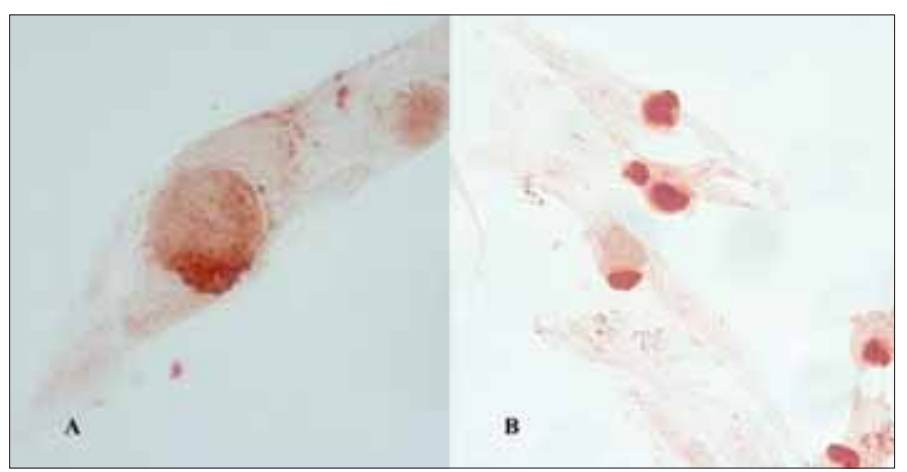

Figure 1 a-b. TUNEL positive cells

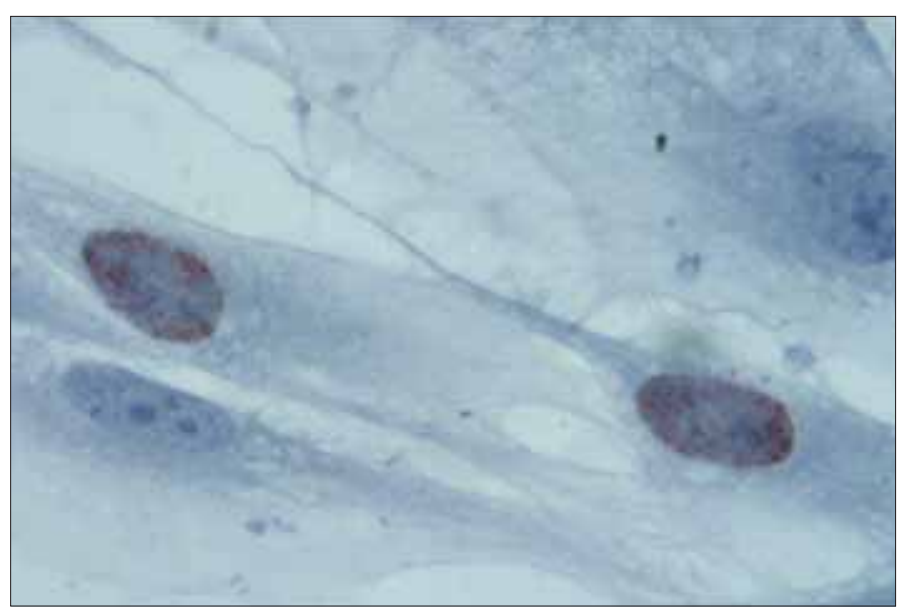

Figure 2. BrdU labeled endometrial cancer cells with light microscopic observation

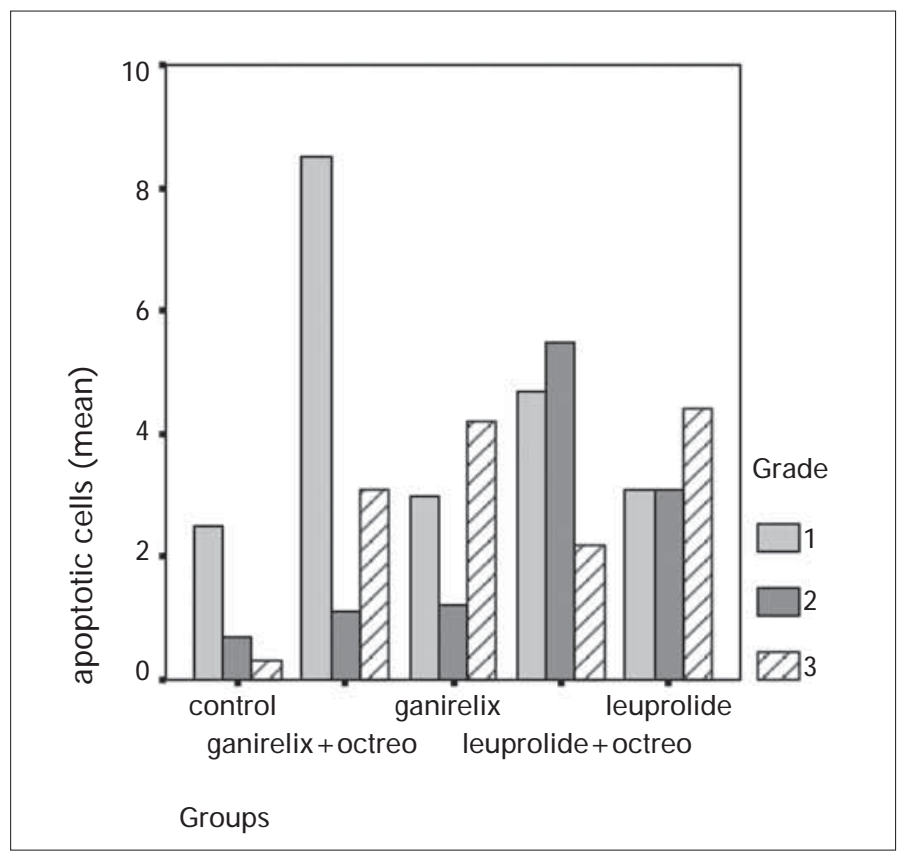

Figure 3. M ean of apoptotic cells in grade I, grade II and grade III endometrial adenocarcinoma, after treatment with $\mathrm{GnRH}$ analogues and analogues plus octreotide 
compared with the ganirelix and leuprolide added groups $(p<0.001, p=0.025$ respectively). However, no additive effect was found with the combination of octreotide on the grade III ECC cell line.

\section{Inhibition of cell proliferation}

The inhibitory effect of ganirelix, leuprolide and their combination with octreotide on three different endometrial cancer cells lines (grade I-II-III) was confirmed using BrdU incorporation into untreated and treated EEC cells in vitro at the $24^{\text {th }}, 48^{\text {th }}$ and $72^{\text {th }}$ hours. BrdU labeled cells among ganirelix (2.6 \pm 0.22$)$, ganirelix and octreotide $(3.7 \pm 0.26)$, leuprolide treated cells $(3.9 \pm 0.1)$ were respectively lower than the number in untreated controls $(7.8 \pm 0.36)$ which was statiscally significant $(p<0.001)$ at the 24th hour of the study in grade I EEC. The number of BrdU positive cells at the $48^{\text {th }}$ and $72^{\text {th }}$ hours were statistically significant when compared with the controls $(p<0.001)$ (Table 2$)$. The antiproliferative response was also seen in the presence of untreated medium in grade II ECC (Table 3). The combination of ganirelix with octreotide did not produce any variation in cell proliferation compared with that obtained with ganirelix alone in grade I and grade II ECC cell lines, while ganirelix and leuprolide alone therapy groups were found more effective than the combination in the grade III EEC cell line (Table 4).

In grade I ECC, when the decreasing percentiles were compared between the groups, the leuprolide plus octreotide treatment group $(p=0.004)$ and leuprolide treatment group $(p=0.04)$ were found to have significantly higher decrease compared to the control group.

In grade II, no difference was found between the groups. On grade III ECC cell lines, ganirelix plus octreotide $(p<0.001)$ and leurolide plus octreotide $(p<0.001)$ had significantly smaller decrease when compared to the control group.

\section{D iscussion}

$\mathrm{GnRH}$ is the primary hypothalamic regulator of reproductive function. Leuprolide acetate is a GnRH agonistic analogue used to treat a wide range of estrogen dependent disorders. It acts on the anterior pituitary, initially inducing a transient rise in gonadotropin release. With continued administration, $\mathrm{GnRH}$ causes pituitary desensitization leading to suppressed circulating levels of gonadotropins and estrogens and has been used in the therapy of some sex-hormone-dependent cancers, includ- ing breast, prostatic, endometrial and ovarian cancer (8-11). $\mathrm{GnRH}$ antagonists, unlike the agonistic analogues, do not induce an initial stimulation of gonadotropin release but cause immediate and rapid, reversible and dose dependant suppression of gonadotropin secretion by competitive receptor occupancy of GnRH receptors (12). The antiproliferative effects of $\mathrm{GnRH}$-a seem to be not only through the suppression of gonadal steroids, but also a direct effect on cell growth, and a specific binding site for $\mathrm{GnRH}$ has been demonstrated in several tumors responsive to $\mathrm{GnRH}$ agonists (5, 13-15). A second type of $\mathrm{GnRH}$ receptor has been identified in endometrial and ovarian cancer cells, which transmits a significantly stronger antiproliferative effect than GnRH-I receptor. In mammals, GnRH-II is more widely identified than $\mathrm{GnRH}-\mathrm{I}$ in periferal tissues, suggesting that $\mathrm{GnRH}-$-II may have additional functions (16). In a recent in vitro study, GnRHs treatment was found to cause an increase in integrin $\beta 3$ expression and evoked the activation of focal adhesion kinase (FAK), ERK1/2 and p38 MAPK compared to the control (17). GnRH-II treatment increases the expression of DNA damage-inducible gene 45 (GADD45 $\alpha$ ) in endometrial cancer cells (16). GnRH-II induces apoptosis through the binding of GnRH-I receptors, activation of ERK1/2 and p38 MAPK pathways, and induction of GADD $45 \alpha$ signaling. These recent

Table 1. The mean of apoptotic cells in grade I, grade II and grade III endometrial adenocarcinoma, after treatment of GnRH analogues and analogues plus octreotide and their comparisons by groups

\begin{tabular}{|l|c|c|c|}
\hline & $\begin{array}{c}\text { Grade I } \\
\text { (mean } \pm \text { SE ) }\end{array}$ & $\begin{array}{c}\text { Grade II } \\
\text { (mean } \pm \text { SE) }\end{array}$ & $\begin{array}{c}\text { Grade III } \\
\text { (mean } \pm \text { SE ) }\end{array}$ \\
\hline Control & $2.5 \pm 0.167$ & $0.7 \pm 0.153$ & $0.3 \pm 0.153$ \\
\hline Ganirelix+Octreotide & $8.5 \pm 0.671^{*}$ & $1.1 \pm 0.1$ & $3.1 \pm 0.277 * * *$ \\
\hline Ganirelix & $3 \pm 0.149$ & $1.2 \pm 0.133$ & $4.2 \pm 0.389 *$ \\
\hline Leuprolide+Octreotide & $4.7 \pm 0.3^{* *}$ & $5.5 \pm 0.167^{*}$ & $2.2 \pm 0.49$ \\
\hline Leuprolide & $3.1 \pm 0.18$ & $3.1 \pm 0.18^{*}$ & $4.4 \pm 0.819^{*}$ \\
\hline $\mathrm{p}$ value & $<0.001$ & $<0.001$ & $<0.001$ \\
\hline $\begin{array}{l}* \mathrm{p}<0.001 \\
* * \mathrm{p}=0.001 \\
* * * \mathrm{p}=0.002\end{array}$ & \multicolumn{3}{|l}{} \\
\hline
\end{tabular}

Table 2. M ean of B rdU positive cells in grade I EEC cell line, after treatment with GnRH analogues and analogues plus octreotide, their comparisons by groups and the percentage of decreased proliferative cells

\begin{tabular}{|c|c|c|c|c|}
\hline & $\begin{array}{c}24^{\text {th }} \text { hour } \\
\text { (mean } \pm \text { SE ) }\end{array}$ & $\begin{array}{c}4^{\text {th }} \text { hour } \\
\text { (mean } \pm \text { SE ) }\end{array}$ & $\begin{array}{c}72^{\text {th }} \text { hour } \\
\text { (mean } \pm \text { SE ) }\end{array}$ & $\begin{array}{c}\text { Decreasing } \\
\text { percentage } \% \pm \text { SE } \\
\text { (min-max) }\end{array}$ \\
\hline Control & $5.6 \pm 0.42$ & $4.8 \pm 0.2$ & $2.7 \pm 0.26$ & $46.3 \pm 10(-33-71)$ \\
\hline Ganirelix+Octreotide & $3.7 \pm 0.21$ & $3.2 \pm 0.13$ & $1 \pm 0$ & $71.6 \pm 2.5(50-75)$ \\
\hline Ganirelix & $2.6 \pm 0.22$ & $2.4 \pm 0.16$ & $1.1 \pm 0.1$ & $51.6 \pm 8.7(0-66.6)$ \\
\hline Leuprolide+Octreotide & $7.6 \pm 0.26$ & $3.4 \pm 0.16$ & $1 \pm 0.14$ & $86.5 \pm 2.1(71.4-100)$ \\
\hline Leuprolide & $3.9 \pm 0.1$ & $3.5 \pm 0.16$ & $0.4 \pm 0.16$ & $90 \pm 4.08(75-100)$ \\
\hline$p$ value & $<0.001$ & $<0.001$ & $<0.001$ & $<0.001$ \\
\hline
\end{tabular}


Table 3. Mean of BrdU positive cells in grade II EEC cell line, after treatment with GnRH analogues and analogues plus octreotide and their comparisons by groups and the percentage of decreased proliferative cells

\begin{tabular}{|l|c|c|c|c|}
\hline & $\begin{array}{c}\mathbf{2 4}^{\text {th }} \text { hour } \\
(\mathbf{m e a n} \pm \mathbf{S E})\end{array}$ & $\begin{array}{c}\mathbf{4 8}^{\text {th }} \text { hour } \\
(\mathbf{m e a n} \pm \mathbf{S E})\end{array}$ & $\begin{array}{c}\mathbf{7 2}^{\text {th }} \text { hour } \\
\text { (mean } \pm \text { SE })\end{array}$ & $\begin{array}{c}\text { Decreasing } \\
\text { percentage } \% \pm \text { SE }\end{array}$ \\
\hline Control & $7.2 \pm 0.46$ & $1.8 \pm 0.35$ & $1.5 \pm 0.22$ & $77.8 \pm 3.8(57-90)$ \\
\hline Ganirelix+Octreotide & $3.7 \pm 0.36$ & $0.8 \pm 0.13$ & $0.6 \pm 0.16$ & $79.1 \pm 5.9(50-100)$ \\
\hline Ganirelix & $1.9 \pm 0.37$ & $0.9 \pm 0.1$ & $0.3 \pm 0.15$ & $83.3 \pm 11.7(0-100)$ \\
\hline Leuprolide+Octreotide & $3.1 \pm 0.18$ & $1.4 \pm 0.22$ & $0.5 \pm 0.16$ & $81.6 \pm 6.3(50-100)$ \\
\hline Leuprolide & $1.5 \pm 0.22$ & $3 \pm 0$ & $0.2 \pm 0.13$ & $85 \pm 10.6(0-100)$ \\
\hline p value & $<0.001$ & $<0.001$ & $<0.001$ & 0.175 \\
\hline
\end{tabular}

Table 4. M ean of BrdU positive cells in grade III EEC cell line, after treatment with GnRH analogues and analogues plus octreotide and their comparisons by groups and the percentage of decreased proliferative cells

\begin{tabular}{|c|c|c|c|c|}
\hline & $\begin{array}{c}24^{\text {th }} \text { hour } \\
(\text { mean } \pm \text { SE })\end{array}$ & $\begin{array}{c}4^{\text {th }} \text { hour } \\
\text { (mean } \pm \text { SE ) }\end{array}$ & $\begin{array}{c}72^{\text {th }} \text { hour } \\
\text { (mean } \pm \text { SE ) }\end{array}$ & $\begin{array}{c}\text { Decreasing } \\
\text { percentage } \% \pm \text { SE } \\
(\text { min-max })\end{array}$ \\
\hline Control & $5.5 \pm 0.16$ & $5.5 \pm 0.56$ & $2.2 \pm 0.29$ & $59.6 \pm 5.84(20-80)$ \\
\hline Ganirelix+Octreotide & $3.8 \pm 0.24$ & $3.3 \pm 0.21$ & $3 \pm 0.29$ & $16 \pm 11(-50-75)$ \\
\hline Ganirelix & $5.2 \pm 0.41$ & $2.4 \pm 0.16$ & $2.1 \pm 0.1$ & $56.4 \pm 5(25-71.4)$ \\
\hline Leuprolide+Octreotide & $4.5 \pm 0.26$ & $2.3 \pm 0.3$ & $2.4 \pm 0.22$ & $44.1 \pm 6.8(0-80)$ \\
\hline Leuprolide & $7.5 \pm 0.26$ & $7.2 \pm 0.24$ & $1.4 \pm 0.22$ & $81.4 \pm 2.5(66.6-88.8)$ \\
\hline $\mathrm{p}$ value & $<0.001$ & $<0.001$ & $<0.001$ & $<0.001$ \\
\hline
\end{tabular}

studies demonstrated that GnRH related inhibition of endometrial cancer cell proliferation is mediated by $\mathrm{GnRH}$ receptors and also related with mitogenic signal transduction molecules. Ganirelix is a synthetic third generation gonadotropin-releasing hormone antagonist that blocks GnRH receptors in the anterior pituitary gland, preventing endogenous $\mathrm{GnRH}$ from inducing $\mathrm{LH}$ and FSH release. GnRH antagonists have agonistic effects on this type II receptor (18). GnRH II has a strong antiproliferative effect without involving induction of apoptosis. It could be speculated that the additional receptors interact with pathways regulating the cell cycle (19).

Previous in vitro studies have shown that the number of Ishikawa endometrial cancer cells was reduced by the GnRH-I antagonist cetrorelix (SB-75) in a dose-dependent manner (13). This growth inhibitory effect of SB-75 was not found to be associated with a decrease in the number of cells in the $\mathrm{S}$ phase but was associated with an induction of apoptosis (13). The decrease in the rate of apoptosis in grade 3 adenocarcinoma in the drug free group may reflect loss of cell homeostasis control and decreased differentiation. It may stated that there are tissue-specific differences controlling the progression of cancer cells.

Heterogeneity of receptor density appears to be common in endometrial adenocarcinomas as the vast majority of tumors showed substantial receptor heterogeneity of both ER and PR within the tumors. Hormone receptor heterogeneity of endometrial carcinoma has been discussed also in the context of the primary tumors and the metastases having different hormone receptors status (20). In a recent study, J eon et al demonstrated that $\mathrm{GnRH}$ receptor expression was not related to the histotype of endometrial cancer, disease stage, tumor differentiation, lymph node metastasis and myometrial invasion (7). In invitro conditions, GnRH analogues will show their effect via $\mathrm{GnRH}$ receptors. As previously described, $\mathrm{GnRH}$ agonists can induce Fas Ligand production in $\mathrm{GnRH}$ receptor bearing endometrial carcinoma. The Fas Ligand expression linked to the $\mathrm{GnRH}$ receptor activation may mediate the antiproliferative action of $\mathrm{GnRH}$ agonist by increasing apoptosis within the cancer cells, but the GnRH effect was abolished by the addition of the antagonist antide (21). In this presented study, apoptosis was found to be induced in both agonist and antagonist application. The cell culture studies demonstrated an increase in the programmed cell death in the grade I, II and III endometrial adenocancer cell lines at the 12th hour of the treatment groups. However, the proliferation index varied depending on the histological grade, which may contribute to the difference in tumor behavior. These apoptotic and antiproliferative effects occur at micromolar concentrations. In fact, when administrated subcutaneously, plasma concentrations of leuprolide at therapeutic doses are in the nanomolar range (22). Also, blood concentrations of antagonist analogues ranged between 30-60 $\mathrm{ng} / \mathrm{ml}$ with an injected dose of $10 \mathrm{mg} /$ day (18). Previous dose response experiments showed the antiprolifetive effect of the lower concentration of the GnRH analogues in the HEC-la lines and Ishikawa cell lines $(13,23)$. Moreover, primary in vitro cultures are closer to in vivo biology when compared to cancer cell lines. Our results suggest that in endometrial cancer, GnRH is part of a negative autocrine system. This knowledge could help clinicians decide whether to use $\mathrm{GnRH}$ agonistic or antagonistic 
analogue and a combination with octreotide to inhibit cell proliferation, in patients with recurrent and/or advanced disease. However, further studies are needed to evaluate the possible additive roles of somatostatin analogues in endometrial cancer. The insulin-like growth factor-1 (IGF-1) signalling pathway has important roles in regulating cellular proliferation and apoptosis. In vivo carcinogenesis models indicate that high levels of plasma IGF-1 are associated with increased risk of cancer (24). Therapeutic strategies that target the IGF-1 receptors or reduce serum levels of growth factor and IGF-1 may be important for the antineoplastic activity of cancer dependent IGF pathway (25). Many human tumors can express somatostatin receptors. In a series of 28 randomly selected endometrial carcinomas, sst was present in $32 \%$, sst 2 in $39 \%$, sst 3 in $43 \%$, sst in $_{4} \%$ and sst in $4 \%$ of cases. $36 \%$ expressed more than one sst receptor (26). Somatostatin analogue octreotide (SMS 201-995) bind with a high affinity for somatostatin receptors 2 and 5 but show a relatively low affinity for ssr 3 (27). Receptor positive endometrial carcinomas may be a potential target for somatostatin analogues.

There are few reports on the use of $\mathrm{GnRH}-\mathrm{a}$ and somatostatin analogues in Gynecologic Oncology. The use of octreotide in gynecologic tumors is reported as case reports. Preclinical studies on tumor biology on somatostatin and its receptors are still under research. As in vitro studies do not parallel the in vivo milieu, these studies are not yet conclusive. Our study reports the effects of $\mathrm{GnRH}$ agonist, antagonist and octreotide in three different grade endometrium cancer cell lines. They were compared in terms of their effects on apoptosis and proliferation. In summary, the current study suggests that GnRH agonistic and antagonistic analogues and their combination with octreotide induce apoptosis. This may be a part of a therapeutic mechanism. Since we did not evaluate the GnRH receptor expression and the molecular pathway of apoptosis in the presented study, the extent of growth inhibition may be affected by more precisely targeted application of $\mathrm{GnRH}$ analogues on appropriate $\mathrm{GnRH}$ receptor positive cells. Further studies would help provide a better understanding of the molecular mechanisms of apoptosis and cell cycle dynamics.

\section{Conflict of interest}

No conflict of interest is declared by authors.

\section{References}

1. Emons G, Heyl W. Hormonal treatment of endometrial cancer. J Cancer Res Clin Oncol 2000; 126: 619-23.

2. Latta E, Chapman WB. PTEN mutations and evolving concept in endometrial neoplasia. Curr Opin Obstet Gynecol 2002; 14: 59-65.

3. Assunção Guimarães C, Linden R. Programmed cell death. Apoptosis and alternative deathsytles. Eur J Biochem 2004; 271: 1638-50.

4. Arends MJ . Apoptosis in the endometrium. Histopathology 1999; 35: 174-8

5. Imai A, Ohno T, lida K, Fuseya T, Furui T, Tamaya T. Gonadotropin releasing hormone receptor in gynecologic tumors: frequent expression in adenocarsinoma histologic types. Cancer 1994; 74: 2555-61.

6. Völker P, Gründker C, Schmidt O, Schutz KD, Emons G. Expression of receptors for luteinizing hormone-releasing hormone in human ovarian and endometrial cancers: Frequency, autoregulation, and correlation with direct antiproliferative activity of luteinizing hormonereleasing hormone analogues. AmJ Obstet Gynecol 2002; 186: 171-9.

7. Jeon YT, Kim YB, Park SY, Kim JW, Park NH, Kang SB, et al. Gonadotropin- releasing hormone receptor expression in endometrial cancer. IntJ Gynecol Pathol 2009; 28: 19-22.
8. Manni A, Santen R, Harvey H, Lipton A, Max D. Treatment of breastcancer with gonadotropin-releasing hormone. Endocr Rev 1986; 7: 89-94.

9. Iversen P, Suciu S, Sylvester R, Christensen I, Denis L. Zoladex and flutamide versus orchiectomy in the treatment of advanced prostatic cancer. A combined analysis of two European studies, EORTC 30853 and DAPROCA 86. Cancer 1990; 66: 1067-73.

10. Gallagher CJ, Oliver RT, Oram DH, Fowler CG, Blake PR, Mantell BS, et al. A new treatment for endometrial cancer with gonadotropin releasing hormone analogue. Br J Obstet Gynaecol 1991; 98: 1037-41.

11. Emons G, Ortmann O, Pahwa GS, Hackenberg R, Oberheuser F, Schult KD. Intracellular action of gonadotropic and peptide hormones and the therapeutic value of GnRH agonist in ovarian cancer. Acta Obstet Gynecol Scand Suppl 1992; 155: 31-8.

12. Huirne JA, Lambalk CB. Gonadotropin-releasing hormone receptor antagonist. New drug classes. Lancet 2001; 358: 1793-803.

13. Kleinman D, Douvdevani A, Schally AV, Levy J, Sharoni Y. Direct growth inhibition of human endometrial cancer cells by the gonadotropin-releasing hormone antagonist SB-75: Role of apoptosis. Am J Obstet Gynecol 1994; 170: 96-102.

14. Emons G, Muller V, Ortmann O, Schult KD. Effect of LHRH analogues on mitogenic signal transduction in cancer cells. Steroid Biochem Mol Biol 1998; 65: 199-206.

15. Imai A, Ohno T, lida K, Fuseya T, Furui T, Tamaya T. Presence of Gonadotropin-Releasing Hormone Receptor and its messenger ribonucleic acid in endometrial carsinoma and endometrium. Gynecol Oncol 1994; 55: 144-8.

16. Wu HM, ChengJ C, Wang HS, Huang HY, MacCalman CD, Leung PC. Gonadotropin-releasing hormone type II induces apoptosis of human endometrial cancer cells by activating GADD45alpha. Cancer Res. 2009; 69: 4202-8.

17. Park DW, Choi KC, MacCalman CD, Leung PC. Gonadotropin-releasing hormone $(\mathrm{GnRH})-\mathrm{I}$ and $\mathrm{GnRH}-\mathrm{Il}$ induce cell growth inhibition in human endometrial cancer cells: involvement of integrin beta3 and focal adhesion kinase. Reprod Biol Endocrinol. 2009; 7: 81.

18. Emons G, Gründker C, Günthert AR, Westphalen S, Kavanagh J, Verschraegen C. GnRH antagonist in the treatment of gynecological and breast cancers. Endocrine Related Cancer 2003; 10: 291-9.

19. Gründker C, Günthert AR, Millar RP, Emons G. Expression of gonadotropin-releasing hormone II (GnRH-II) receptor in human endometrial and ovarian cancer cells and effects of GnRH-II on tumor cell proliferation. J Clin Endocrinol Metab 2002; 87: 1427-30.

20. Dahmoun M, Backstrom T, Boman K, Cajander S. Apoptosis, proliferation, and hormone receptors in endometrial carsinoma: Results depending on methods of analysis. IntJ Oncol 2003; 22: 115-22.

21. Imai A, Takagi A, Horibe S, Takagi H.Tamaya T. Evidence For Tight Coupling of Gonadotropin-Releasing Hormone Receptor to Stimulated Fas Ligand Expession in Reproductive Tract Tumors: Possible Mechanism for Hormonal Control of Apoptotic Cell Death. J Clin Endocrinol Metab 1998; 83: 427-31.

22. Noci I, Coronnello M, Borri P, Borrani E, Giachi M, Chieffi O, et al. Inhibitory effect of luteinising hormone-releasing hormone analogues on human endometrial cancer in vitro. Cancer Lett 2000; 150: 71-8.

23. Emons G, Schröder B, Ortmann O, Westphalen S, Schulz KD, Schally AV. High affinity bindign and direct antiproliferative effects of luteinizing hormone-releasing hormone analogs in human endometrial cancer cell lines. J Clin Endocrinol Metab 1993; 77: 1458-64.

24. Pollak MN, Schernhammer ES, Hankinson SE. Insulin-like growth factor and neoplasia Nature Reviews Cancer 2004; 4: 505-18.

25. Pollak MN, Schally AV. Mechanism of antineoplastic action of somatostatin analogs. Proc Soc Exp Biol Med 1998; 217: 143-52.

26. Schulz S, Schmitt J, Weise W. Frequent expression of immunoreactive somatostatin receptors in cervical and endometrial cancer. Gynecol Oncol 2003; 89: 385-90.

27. Mishima M, Yano T, J imbo H, Yano N, Morita Y, Yoshikawa H, et al. Inhibition of human endometrial cancer cell growth in vitro and in vivo by somatostatin analog RC-160. AmJ Obstet Gynecol 1999; 181: 583-90. 